Research Article / Araştırma Makalesi

\title{
INCREASING THE SOCIAL INTEGRATION OF SYRIAN REFUGEES IN TURKEY THROUGH VOCATIONAL EDUCATION AND TRAINING
}

\author{
Prof. Dr. Mahmut ÖZER (D) \\ Ministry of National Education, Ankara, Turkey, (mahmutozer2002@yahoo.com) \\ Dr. H. Eren SUNA 10 \\ Ministry of National Education, Ankara, Turkey, (herensuna@gmail.com) \\ Prof. Dr. K. Varım NUMANOĞLU (D) \\ Ministry of National Education, Ankara, Turkey,(varimk@yahoo.com)
}

\begin{abstract}
Turkey currently hosts the largest amount of Syrian refugees with a population of around 3.9 million. Besides housing and health supports, Turkey has been doing its best to increase their schooling ratio in the light of new legislation and laws. These efforts also include vocational education and training (VET) which has been a useful tool to ensure the adaptation of immigrants in many countries with flexible solutions. In this study, we present and evaluate the VET projects carried out by the Ministry of National Education (MoNE) for adaptation of Syrian refugees, considering the best practices and recommendations of international organizations. The results show that the MoNE projects correspond with international criteria by informing refugees about VET, preparing them for the educational process, facilitating their participation, and supporting them throughout their experiences.
\end{abstract}

Keywords: Syrian Refugees, Employment, Vocational Education and Training, Turkey, Labor Market.

\section{TÜRKIYE'DEKI SURIYELİ GÖÇMENLERIN MESLEKI VE TEKNIK EĞITIMM ARACILIĞIYLA SOSYAL UYUMUNUN ARTIRILMASI}

\begin{abstract}
ÖZET
Türkiye, mevcut durumda yaklaşık 3,9 milyon Suriyeli göçmene ev sahipliği yapmakta ve en fazla göçmenin bulunduğu ülkeler arasında yer almaktadır. Sunduğu yerleşim ve sağlık hizmetlerinin yanı sira Türkiye yeni düzenlemeler ve kanunlar ışı̆̆ında göçmenlerin okullaşma oranlarını artırmak için de önemli bir çaba harcamaktadır. Bu çabalar, sunduğu esnek çözümler ile birçok ülkede göçmenlerin uyumunu sağlamak için sik kullanılan bir araç olan mesleki ve teknik eğitimi de kapsamaktadır. Bu çalışmada Milli Ĕ̆itim Bakanlığı (MEB) tarafından mesleki ve teknik eğitim aracılığıyla göçmenlerin uyumunu sağlamak amacıyla gerçekleştirilen projelerin uluslararası kuruluşların iyi uygulama örnekleri ve önerileri dikkate alınarak değerlendirilmesi amaçlanmıştır. MEB tarafindan uygulanan projelerin göçmenleri mesleki ve teknik eğitimle ilgili bilgilendirme, ĕ̆itim sürecine hazırlama, katılımlarını kolaylaştırma ve süreç boyunca destekleme boyutlarında uluslararası ölçütlerle büyük bir uyum içinde olduğu sonucuna varılmıştır.
\end{abstract}

Anahtar Kelimeler: Suriyeli Göçmenler, İstihdam, Mesleki ve Teknik Ĕ̆itim, Türkiye, İşgücü Piyasası. 


\section{Introduction}

Globalization and increased international human mobility have led to an increase in the number of immigrants. Migrations are associated with wars, political pressures, and human conflicts far beyond simply seeking better living conditions. The global number of immigrants, which more than tripled between 1960 and 2009, has accelerated greatly since the 2000s (Nusche, 2009; United Nations, 2015). In particular, the Syrian civil war has contributed significantly to this increase. In 2015, the number of people forced to leave their home region reached its highest level since World War II (UNESCO \& UNHCR, 2016). According to the estimates of the United Nations High Commissioner for Refugees (UNHCR) and Educational, Scientific, and Cultural Organization (UNESCO), more than 60 million people were forcibly displaced from their homes in 2015, approximately 16.1 million of whom were refugees (UNESCO \& UNHCR, 2016). The large increase in the number and diversity of immigrants creates great global uncertainty (Czaika \& de Haas, 2014); thus, migration is an important problem that concerns all countries (CEDEFOP, 2017; Deniz, 2014). This situation pushes countries to evaluate the effectiveness of their immigration integration policies.

Receiving education is among the most basic of human rights, regardless of an individual's social or economic background (Beiter, 2006; UNESCO, 2015). The poor life circumstances experienced by immigrants can limit their participation in education and lead to their withdrawal from education for various reasons (Fernandez, 2017; UNESCO \& UNHCR, 2016). This means that immigrants cannot enjoy their basic rights for reasons they cannot control (Fernandez, 2017). Immigrants are up to five times more likely to be unable to continue their education than other students (UNESCO \& UNHCR, 2016). For this reason, it is important that countries develop effective policies to monitor the education of immigrants and ensure educational continuity for this vulnerable population (Willems \& Vernimmen, 2018). International organizations such as UNICEF, OECD, and the World Bank emphasize the importance of education for migrants and provide application examples to ensure migrant adaptation through education (Jeon, 2019; Khunyu Khsioni, 2016; UNESCO, 2015; UNESCO, 2019). This study aims to introduce and evaluate the projects carried out through Turkish vocational education and training (VET) system to ensure the integration of Syrian refugees with formal labor market based on the criteria of international organizations including UNICEF, OECD and World Bank.

\section{Education as The Main Source of Integration of Immigrants}

Education is the most important tool countries have to ensure the social integration of immigrants and refugees (British Council, 2018; De Paola \& Brunello, 2016; Jeon, 2019; UNESCO, 2019). Education provides wider opportunities for immigrants and refugees due to the social, academic, and professional skills it cultivates in students (Bonin, 2017; CEDEFOP, 2011; Fazel et al., 2012; Hanushek et al., 2017; Koehler \& Schneider, 2019; OECD, 2018a). In addition, while they benefit from the education system of the countries they migrate to, they may also be affected by the disadvantages of these existing education systems, which can compound the effects of discrimination they face. The differences between schools and the school tracking scale can perpetuate these issues (Crul, 2019). Moreover, there is a strong relationship between school achievement differences, socioeconomic level, and academic 
achievement (Berberoğlu \& Kalender, 2005; Bölükbaş \& Gür, 2020; Dinçer \& Uysal Kolaşin, 2009; ERG, 2014; Gençoğlu, 2019; Karaağaç Cingöz \& Gür, 2020; Önder \& Güçlü, 2014; Özer, 2021; Özer, 2020; Suna et al., 2020a; Suna et al., 2020b; Suna \& Özer, 2021a; Suna \& Özer, 2021b; Suna et al., 2020). Consequently, immigrants often end up in the types of schools that are most affected by these achievement gaps. As a result of school tracking which increases the role of parental privilege (Brunello \& Checci, 2006), the disadvantage of immigrants may increases more. In particular, in countries such as Germany, where school tracking begins at an early age, refugees are typically only able to find a place in vocational education and training (VET) institutions (Aerna \& Bonoli, 2021; Crul et al., 2019). In these types of nested and hierarchical education systems, refugees' access to higher education may be extremely limited, thereby undermining their chances to excel in society (Koehler \& Schneider, 2019).

On the other hand, VET provides perhaps the easiest transition to education in hierarchical education systems, as it helps to compensate for the length of time necessary to learn a new language, the inadequacy of prior educational experiences, and interruptions to refugees' previous learning due to war or other traumatic circumstances (Crul et al., 2019). Therefore, with the increase in the number and diversity of refugees in recent years especially due to Syrian war, VET has risen to prominence in the adaptation of refugees (Alla-Mensah et al., 2019; CEDEFOP, 2017; Jeon, 2019; Kuczera \& Jeon, 2019). Many countries with large refugee populations consider that VET systems have a great potential for integration of immigrants. VET focuses mainly on vocational skills and on-the-job training to facilitate immigrants and refugees' transitions to the labor market (British Council, 2018; CEDEFOP, 2017; Jeon, 2019). Immigrants are able to transition into the foreign education system with greater ease because of the VET system's limited number of courses focusing on academic skills. In addition, students' language skills are less determinant of their achievement in VET compared to academic education. However, immigrants and refugees often face difficulties accessing VET, particularly in countries where dual VET is implemented, because employers may have negative attitudes towards immigrants and refugees, making it difficult for these students to receive on-the-job skills training (Aerna \& Bonoli, 2021; Protsch \& Solga, 2017; Zschirnt \& Ruedin, 2016). In this case, they can only be directed to VET industries with inadequate local employees (Aerna \& Bonoli, 2021). Despite these drawbacks, VET generally mitigates the educational disadvantages faced by immigrants and refugees and enables them to enter the labor market in a shorter time thanks to its focus on professional skills.

Turkey has been a primary destination of migration movements over the last decade due to wars in surrounding regions (Emin, 2016; Emin, 2019; Günay et al., 2017). Due to the migration movements that began in Arab countries in 2011, particularly the Syrian Civil War, Turkey has seen more migration than nearly any other nation (Çelik \& İçduygu, 2018; Turk, 2019; UNEVOC, 2019). According to the UNHCR, there are more than 3,930,000 refugees and asylum seekers in Turkey as of 2021, making up about $4 \%$ of the national population. Additionally, $33.7 \%$ of Syrian immigrants, who make up the majority of immigrants in Turkey, are between the ages of 5-18. In other words, there are more than 1,232,000 school-aged Syrian immigrant children living in Turkey - a number greater than the entire student population of many countries. Integrating these students into the Turkish education system and empowering them to benefit from educational opportunities pose many challenges for Turkey. 
Important steps have been taken for the education of Syrian children, whose numbers in Turkey have been growing rapidly for nearly a decade (Emin, 2016; Emin, 2019; Kılıç \& Özkor, 2019; Tüzün, 2017). Since 2011, Turkey implemented several short-term policies at the beginning, but as of 2014, it initiated several long-term policies in order to increase Syrian refugees' access to education, health and employment (Adalı \& Türkyılmaz, 2020; Çelik \& İçduygu, 2018; Unutulmaz, 2019). Thanks to the Foreigners and International Protection Law No. 6458 (YUKK) and Temporary Protection Regulation issued in 2014, refugees under "Temporary Protection" have the right to education in public schools where they live, in addition to temporary education centers (TEC) (Emin, 2016; Emin, 2019). Syrian refugees can receive education in refugee camps, TECs inside and outside of the camps, public schools, and private schools opened by Syrians. In 2016, the Turkish Ministry of National Education (MoNE) took an important step in cooperation with the European Union to initiate the "Support for the Integration of Syrian Children into the Turkish Education System Project" (PICTES) (Tuzun, 2017). Currently, 1,082,172 Syrian students between the ages of 5-17 are being educated within the scope of the project, which is carried out in 26 provinces. Through the project, students receive Turkish and Arabic language support, participate in remedial and support courses to eliminate basic skill deficiencies, and receive support for foundational and educational material needs free of charge. Thanks to these interventions, the schooling rate of Syrian refugee children in primary school has reached 98\% nationally (Kılıç \& Özkor, 2019; MEB, 2018).

The 2014 regulations promoted the permanent inclusion of the refugees in the education system, and as of 2016, the PICTES program has significantly increased the schooling rate at the primary level (Nur, 2016; Nur, 2019). However, the integration was not so easy at the secondary and postsecondary levels (Emin, 2019; MEB, 2013). On the other hand, since the Syrian population in Turkey seems to be younger than the Turkish population (Adalı \& Türky1lmaz, 2020), the MoNE took another important step for the integration of the refugees in 2020 by designing new projects to encourage their participation in labor market through VET. In cooperation with the German Development Bank (KfW), the MoNE initiated the "Social and Economic Cohesion I and II" projects and the "Facilitating the Access of Syrian and Host Communities to Employment through Quality Apprenticeship and Vocational Education in Turkey Program." These projects are critical for increasing the secondary school enrollment rates of the Syrian refugees who have been gradually integrated into the Turkish education system since 2014, as well as for bolstering their employment opportunities through the training and networking provided by VET (Özer, 2021a). They are also of great importance to decrease informal participation in labor market, which constitutes a challenging issue (İçduygu \& Diker, 2017; Siviş, 2020). Therefore, this study aims to introduce and examine the projects carried out through Turkish VET to ensure the integration of Syrian refugees with formal labor market, and to evaluate the current situation and the plans made in line with international criteria: informing immigrants about the opportunities of VET, ensuring that refugees are prepared for VET, facilitating the transition of immigrants to VET, and supporting refugees during VET. Based on general aim, following research questions are sought to answer with a broad perspective;

1. How compatible are the VET projects of MoNE for integration of immigrants to the criteria of informing immigrants about the opportunities of VET? 
2. How compatible are the VET projects of MoNE for integration of immigrants to the criteria of ensuring immigrants' preparedness towards VET?

3. How compatible are the VET projects of MoNE for integration of immigrants to the criteria of facilitating the transition of immigrants to VET?

4. How compatible are the VET projects of MoNE for integration of immigrants to the criteria of supporting the immigrants during VET?

\subsection{Vocational Education and Training for Integration of Immigrants: Advantages and Limitations}

In many countries, the opportunities offered by VET are considered as the main tool for ensuring the adaptation of immigrants (CEDEFOP, 2017; Jeon, 2019). VET is a type of education that prepares students for the job market in a relatively short time frame by providing them with the skills necessary to succeed in their profession (CEDEFOP, 2017; Özer, 2018; Özer, 2019a; Özer, 2019b; Özer \& Perc, 2020; World Bank, 2019). According to the International Labor Organization (ILO), approximately $90 \%$ of the immigrants in the world are of working age (Ragazzi \& Sella, 2013). VET has the potential to increase the employability of these individuals (Kuzcera, 2017; Kuczera \& Jeon, 2019), addressing the critical need for immigrants to make economic gains and receive social and economic rewards for their skills so that they can adapt to their new society by leaving behind their previous adverse circumstances.

The language barrier is perhaps the greatest obstacle that immigrants face in their adaptation to their new society (De Paola \& Brunello, 2016; Jeon, 2019; UNEVOC, 2019). Immigrants often are not proficient in the language of their communities, and it takes time for them to acquire these skills. The fact that VET focuses mainly on vocational skills allows immigrants with limited language proficiency to acquire professional skills while continuing their language education, thus enabling them to adapt more quickly.

VET is designed to train qualified human resources for different professions (CEDEFOP, 2011; OECD, 2009; Özer, 2020a; Özer, 2020b; Özer \& Suna, 2020). Students have the opportunity to choose professions that they are interested in and that they think are compatible with their skills. The fact that VET offers a greater diversity of vocational options to students than traditional academic education makes it an ideal option for immigrants. Furthermore, VET employment opportunities typically do not require further post-secondary education, making them more viable in the short term for immigrants seeking to get on their feet quickly. Thanks to its flexible structure, immigrants can also receive training in more than one professional field if they meet certain achievement standards. If an immigrant student already has vocational skills, they can hone these skills within the scope of their previous training and can seek credit or certification based on standards for equivalence.

Immigrants are a highly heterogeneous group (Jeon, 2019; UNEVOC, 2019). The socioeconomic background of migrants and refugees varies significantly according to many variables, including age, language skills, and academic skills. This means that different subgroups of immigrants have different educational needs. Structuring VET for different professions and prioritizing practical skills offers a greater array of options to meet the educational needs of a diverse immigrant population. 
In many countries, students' orientation towards VET tend to grow more negative at the secondary education level (Jeon, 2019). However, VET is often preferred by students from lower socioeconomic and academic success levels, who also have lower expectations of education (Foster, 2007; Özer, 2020c; Özer, 2020d; Özer, 2021b). The pathing of VET students away from higher education, combined with negative societal perceptions of VET, tend to discourage students from choosing this type of education. As a result, the proportion of students enrolling in VET has been steadily declining in many OECD countries over the past decade (Jeon, 2019). If this trend continues, it could reduce the diversity of students in VET, thus limiting the availability of graduates with the vocational skills required by the labor market. On the other hand, because immigrants or refugees are in greater need of the opportunities provided by this type education, many countries see directing them to VET as an opportunity to solve this problem. Given the current context, this alignment makes VET an important tool in the integration policies.

Despite all the opportunities offered by VET, ensuring the integration of immigrants through this type of education also involves numerous challenges (CEDEFOP, 2017; Jeon, 2019; UNEVOC, 2019). First, research has indicated that many immigrants prefer academic education over VET (Jeon, 2017), due to insufficient awareness of the opportunities offered by VET, as well as lack of knowledge about the structure of the education system and the expectations of the labor market of the country (CEDEFOP, 2017; UNEVOC, 2019). Moreover, the perception of VET by immigrants in their own countries may also be negative, creating preconceived notions that may be difficult to dismantle.

\subsection{Vocational and Technical Education Projects in Turkey for The Integration of Immigrants}

In 2020, the MoNE started to take important steps to ensure the integration of Syrian refugees through VET. The most comprehensive studies carried out in this context were a part of the "Social and Economic Integration through Vocational and Technical Education I and II" projects. These projects aimed to encourage the participation of Syrian refugees in VET and increase the quality of their education. This project was financed by the "Financial Assistance Program for Refugees in Turkey" (FRIT) fund with the support of the German Development Bank (KfW).

\subsubsection{Social and Economic Integration Through Vocational and Technical Education I (SEUP I)}

The first project in this area was designed to increase the quality of VET, while simultaneously facilitating the vocational and social adaptation of Syrian refugees. Budgeted at 50 million Euros, the project timeline was planned for 2018-2022. To increase the quality of education, the infrastructures of the VET high schools included in the project were strengthened through updates and equipment support. The project identified and met the needs of 1,154 workshops in 55 VET high schools in eight provinces where Syrian refugees are predominant. Additionally, hardware supports were integrated to strengthen training environments, as well as increasing the quality of training processes through improved regulations in accordance with occupational health and safety procedures. 
Within the scope of the project, support packages were created to provide the materials needed by students in these programs. Tablets were distributed to 4,500 students to facilitate access during the pandemic period, and meal cards were distributed to reduce monthly food costs. Moreover, 1,819 students were provided with school uniforms and 814 students were provided with practical materials. These supports bolstered the educational enrollment of students in VET. Support packages were provided to approximately 10,000 students in the three years following the initiation of the project.

Communication activities and promotions were initiated to increase Syrian refugee students' awareness of the project and encourage them to maximize the benefits available. Program representatives made visits to the homes of Syrian refugee families and refugee camps. Informational brochures in both Turkish and Arabic were prepared and distributed to the children and their families. Press conferences were held in the provinces with VET high schools included in the project. Workshop openings and school improvements were announced through community meetings, and promotions also were broadcast on various television channels and the Education Information Network (EBA). In addition to these activities, breakfasts with business partners and media, informational days, and two national conferences with 150 participants each were planned to raise awareness of the project.

\subsubsection{Social and Economic Integration Through Vocational and Technical Education II (SEUP II)}

The second project, also a partnership between the MoNE and KfW, was launched on December 29, 2020. The second stage, budgeted at 75 million Euros, aims to expand the gains achieved in the first stage. During this stage, more than 50 VET high schools in 15 provinces will be improved across several dimensions. Provinces with 50,000 or more immigrant residents were prioritized in this phase. As in the first phase of the project, the supports are designed to improve the infrastructure and equipment of educational institutions.

The scope of the assistance provided will increase in the second phase, with over 30,000 Syrian refugee students receiving a support package, and over 10,000 receiving transportation support during their four years of education. In addition to this aid, 15,000 students and their families will receive in-kind support. The support provided will make a significant contribution to students' orientation to VET and enable them to continue their education.

The MoNE has also developed plans to increase participation in the project through boosting its visibility. Representatives will make over 10,000 family visits to promote the project, hold 30 information meetings in different provinces, prepare a spot film to be broadcast on television, publicize the project on social media channels, and hold information sessions and press conferences.

The project emphasizes steps to expedite the employment of Syrian refugees who have completed their vocational training. Representatives from different sectors have agreed to provide on-the-job training for them in business environments. Thus, Syrian refugees will have more opportunities to develop vocational skills in real world settings, to learn about business cultures and working environments, and to understand the expectations of the formal labor market. These businesses have also agreed to prioritize employment for project graduates 
within the scope of the project. To support this goal, the project budget covers one-year salaries for 1,500 graduates.

\subsubsection{Program for Facilitating The Access of Syrian and Host Communities to Employment Through Quality Apprenticeships and Vocational Training in Turkey (IMEP)}

An additional project by the MoNE, IMEP, aims to ensure the adaptation of different groups of refugees through VET. This project was started in 2020 alongside SEUP I and II and is planned to last for four years. The project is budgeted at approximately 30 million Euros, financed by the European Union Fund.

The most basic feature of IMEP that distinguishes it from SEUP is that it focuses on apprenticeship training and targets different age groups among refugees. Apprenticeship programs are the most predominant form of training within VET (MoNE, 2018; Özer, 2018; Özer, 2019a; Özer, 2019b). Apprenticeships in vocational training centers (VTCs) in Turkey are carried out within the scope of a program where students learn in school for one day each week and receive on-the-job training for four days. The focus on apprenticeship in IMEP is designed to help refugees gain professional skills so that that they can enter the labor market quickly.

This project targets high school immigrant students aged 14-17 and adults aged 18-45. To ensure that Syrian students between the ages of 14-17 receive qualified apprenticeship training, the infrastructures of VTCs in 12 provinces have been improved and equipment support has been provided. These improvements will enable 14,400 Syrian students to receive education at VTCs.

VET for adults will be performed in Adult Training Centers (ATCs). Similar to VTCs, the physical infrastructure of these institutions has been enriched. As a part of this project, 8,000 Syrian refugees are expected to attend VET for adults. To increase the quality of the training, 5,000 educators representing the selected sectors, as well as 350 personnel from VTCs and ATCs will be employed.

This program also initiates intensive language development courses to address language barriers, as well as social cohesion activities for the 36,800 refugees participating in the project. Communication campaigns were launched to reach 80,000 people, including Syrian refugee students, adults, and industry employees, to raise awareness about the project.

\section{Method}

The present study uses document analysis to evaluate the coherence between the VET projects of MoNE for the integration of immigrants through the emphasized international criteria. Document analysis presents researchers a framework for reaching the valid resources and review these resources in a logical and systematic perspective (Bowen, 2009). Within this perspective, the VET projects of MoNE for the integration immigrant students are introduced broadly, then criteria which are emphasized by international organizations are discussed. Lastly, the coherence between the projects and the international criteria is reviewed in details. 


\section{Findings}

\subsection{Evaluation of MoNE Projects According to International Criteria}

The use of VET to ensure the integration of refugees depends on the effective implementation of projects based on contextual factors. The effective implementation of VETrelated projects for immigrants is critical for three reasons; firstly, the governments invest greatly for large-scale educational projects for supporting the integration of immigrants. From the financial perspective, quality of implementation is important for the investment return (Bonin, 2017). Secondly, the quality of these projects is also important at the society-level. When these large-scale projects are implemented well, both the immigrants and the native society benefit from positive results such as increased employability of immigrants (OECD, 2014). International organizations like OECD and UNEVOC examine the integration policies of different countries through VET and offer recommendations to optimize results (British Council, 2018; CEDEFOP, 2007; Jeon, 2019; Nusche, 2009; UNEVOC, 2019). This section outlines these suggestions and uses them to evaluate the compatibility of the SEUP and IMEP projects developed by the MoNE.

\subsection{Informing Immigrants About The Opportunities of Vocational Education and Training}

The economic, social, and linguistic disadvantages faced by immigrants can hamper their integration into their new communities and limit their knowledge of the opportunities provided by VET. The structure of VET, which differs according to the field(s) of practice selected by the student, can be difficult for immigrants to understand. For this reason, promotional campaigns and informational materials for immigrant programs are extremely important. Such initiatives should prioritize direct communication with immigrants, monitor their interest in VET, evaluate pre-learning and skills, and take measures against the problems they may encounter during the education process.

The MoNE's allocation of human and financial resources to inform refugees of the SEUP and IMEP programs is an important step, in this regard. These projects have involved direct interviews with refugee students and their families, as well as the effective use of promotional and informational campaigns on social media, television, and other communication channels. Informational interviews are used to collect information on students' existing vocational skills and their experiences with VET. A language support program was also created within the scope of IMEP to help immigrant students address a major obstacle to integration. Similarly, providing student support packages, transportation, and in-kind aid for refugees to start and maintain education are other important steps taken under this umbrella.

\subsection{Ensuring That Refugees Are Prepared for Vocational Education and Training}

The traumatic experiences of refugees can make it difficult for them to pursue education in their new environment. Students may feel inadequate due to deficiencies in language or cognitive skills, leading to them to hesitate to enroll. For this reason, the recent Turkish projects emphasizes policies to encourage the educational participation of Syrian refugee students and support them inside and outside of the classroom. Crucial among these policies are the programs designed to bolster students' language and other foundational skills prior to VET. 
Moreover, these projects have also created programs to facilitate students' social adaptation and provide guidance on the structure of the national education system and job market. Since refugees are a very heterogeneous group, the program will ideally provide educational services in more than one language.

One of the common goals of SEUP and IMEP is to provide multi-dimensional support to refugees to enable their success in VET. Both projects incorporate programs, implemented simultaneously with VET, to accelerate the social adaptation of students and compensate for their basic skill deficiencies. It is also important that these programs provide trainings for a wide array of professions to create options for learners with different interests and needs. Education experts involved in SEUP and IMEP have also been trained on the characteristics of the refugee group and the scope and process of the project. It is anticipated that these steps will provide significant support to immigrants both before and during the education process, thus fostering their success in VET.

\subsection{Facilitating The Transition of Refugees to Vocational Education and Training}

In many education systems, refugees enter with competencies below the criteria required to participate in VET. It is not realistic to expect immigrants, particularly those who have recently fled political unrest, war or who are processing traumatic experiences, to immediately meet the general criteria of the educational system of a country that is strange and new to them. Thus, it is important to develop policies to facilitate their transition to formal labor market through the VET. In this context, it is recommended that the criteria used in VET admissions be minimized for refugee students. However, to maintain the quality of VET, there is a need to continuously support the basic and vocational skills of refugees from foundational courses and programs. Considering the heterogeneity of refugees and their expected skill levels at graduation, creating group-specific training programs can also be an option. It is important to distribute vocational programs for refugees by province based on the needs of both students and employer, to avoid skill mismatch when graduates transition into the labor market. Updating classrooms and facilities to increase the quality of education is also emphasized. Finally, the international literature explains that it is beneficial to for immigrants to interact with the local labor market and its representatives throughout their education process (OECD, 2018b).

Both SEUP and IMEP facilitate refugees' transition by removing criteria that could exclude them from participating in VET. During the adjustment process, all students are provided with language and basic skills support to increase the quality of their vocational training. The physical infrastructure of all schools and centers included in the projects has been improved through cooperation with KfW. All teachers and experts involved in SEUP and IMEP are provided with training on refugees and the project process, emphasizing the special needs and heterogeneity of the group. The schools, VTCs, and ATCs involved in the project are located in the provinces with the largest refugee population, and the available vocational fields are determined by considering the local labor market needs. Experts from the labor market participate in the training process to establish a relationship between businesses and migrants that will continue throughout the project. Therefore, concrete steps have been taken in SEUP and IMEP to ensure the participation of refugees in VET. 


\subsection{Supporting Refugees During Vocational Education and Training}

Supporting refugees throughout VET is important to foster their achievement and reduce drop-out rates. Guidelines to meet this objective include mitigating students' skill deficiencies during the initial stage, implementing activities to increase social adaptation, and providing individual support whenever possible. It is important for project personnel to recognize that refugees are a fragile group, and to consult with experts if they encounter problems. In addition, the projects emphasize the importance of conducting on-the-job training in real working environments and maintaining connections between refugees and the business world during the training process.

The projects initiated by the MoNE include a support policy extending from preeducation to employment is pursued to sponsor refugees during their training. At the beginning of the projects, refugees are given language support and training to compensate for their basic skill deficiencies. Social adaptation programs also continue throughout the training, including psycho-social support provided by counselors working in the schools within the scope of the project. Companies in the relevant sectors have agreed to provide on-the-job training for refugee students participating in the project and prioritize hiring IMEP graduates. Experts involved in the project have received extensive training on the target group's characteristics, as well as the plans for project implementation. Therefore, the steps taken in these projects are designed to support Syrian refugees academically and socially throughout their education.

\section{Discussion and Conclusion}

The spike in migration in recent years has increased the importance of policies aimed at ensuring the social cohesion of migrants (UNESCO, 2019; UNEVOC, 2019). Many countries use VET as an effective tool in such adaptation policies (British Council, 2018; Jeon, 2019; Kuzcera \& Jeon, 2019). VET provides important educational opportunities for immigrants by offering flexible solutions to students, concentrating on practical education, and mitigating the effects of existing skill deficiencies. VET has the potential to help immigrants attain higher levels of education, gain professional skills, and transform these skills into economic gain with the opportunities it offers (Jeon, 2019; Kuzcera \& Jeon, 2019).

Turkey is a country experiencing the highest rate of immigration over the last decade; thus, its policymakers attach great importance to facilitating the integration of Syrian refugees (Türk, 2019; UNEVOC, 2019). After increasing the participation of Syrian refugees in primary school through the PICTES project, the MoNE has fixed its attention on strengthening their enrollment in secondary education, which is still low. In this context, the large-scale SEUP I \& II and IMEP projects launched in 2020 coincide with the best practices emphasized by international organizations in refugees' education. The projects plan to provide multi-level support to Syrian students and families before, during, and after education through agreements made with experts and businesses. Equipping the students and adults with vocational skills will benefit their social integration as well as economic status. For this reason, these projects include supports to facilitate employment after training. Therefore, these new projects have potential for Syrian refugees' access to formal labor market easier through VET (İçduygu \& Diker, 2017; Siviş, 2020; Şimşek, 2019). Although Germany advanced more on labor market integration of Syrian refugees' through its famous dual VET system (OECD, 2017; Tanrikulu, 2020), Turkey now initiates to use that instrument by these new projects. 
Ensuring the adaptation of Syrian refugees through VET can also help address some of the VET system's current problem areas. Studies on the education of refugees show that young people from this group tend to start working instead of pursuing secondary education, typically for financial reasons (Emin, 2019). Similarly, despite the language support provided in the PICTES project, language proficiency has not yet reached adequate levels in some student groups. High dropout rates for migrants at the secondary and high school levels (Emin, 2016; Emin, 2019; Tanrıkulu, 2017; Taşkın \& Erdemli, 2018; Tunga et al., 2020) could be explained by teachers' limited familiarity with the needs of immigrant students (Taştan \& Çelik, 2017; Tunga et al., 2020), inadequacies in educational settings (Taştan \& Çelik, 2017), inadequate teacher training (Emin, 2016; Emin, 2019; Tüzün, 2017), and a lack of systematic approach to education (Beltekin, 2016). The steps taken within the scope of the SEUP I \& II and IMEP projects may lead to significant improvements in these areas. Given these needs, the MoNE has taken many methodical steps to strengthen VET in recent years (Özer, 2018; Özer, 2019a; Özer, 2019b; Özer, 2021b; Özer, 2021c). Supporting VET high schools and vocational training centers through new projects aimed at increasing the access of Syrian refugees to VET will also contribute to this movement (Özer, 2021a).

The research ethics are considered and all authors have contributed equally in diverse stages of article.

\section{References}

Adalı, T. \& Türkyılmaz, A. S. (2020). Demographic data on Syrians in Turkey: What do we know? International Migration, 58(3), 196-219

Aerne, A. \& Bonoli, G. (2021). Integrating through vocational training: Promoting refugees' access to apprenticeship in a collective skill formation system. Journal of Vocational Education and Training.

Alla-Mensah, J., Fakoush, H., McGrath, S. \& Wedekind, V. (2019). Migrants in the labor market: Implications for TVET. In S. McGrath, M. Mulder, J. Papier, R. Suart (Eds.), Handbook of vocational education and training (pp. 159-177). Springer.

Beiter, K. D. (2006). The protection of the right to education by international law. International Studies in Human Rights, 82.

Beltekin, N. (2016). Turkey's progress toward meeting refugee education needs the example of Syrian refugees. Eurasian Journal of Educational Research, 66, 175-190.

Berberoğlu, G. \& Kalender, İ. (2005). Investigation of student achievement across years, school types and regions: SSE and PISA analyses. Educational Sciences and Practice, 4(7), 21-35.

Bonin, H. (2017). The potential economic benefits of education of migrants in the EU. IZA Research Report No. 75. https://ftp.iza.org/report_pdfs/iza_report_75.pdf

Bowen, G. (2009). Document analysis as a qualitative research method. Qualitative Research Journal, $9(2), 27-40$.

Bölükbaş, S. \& Gür, B. S. (2020). Tracking and inequality: The results from Turkey. International Journal of Educational Development, 78, 102262.

British Council (2018). Inclusion of refugees in technical and vocational education and training: An exploration into funding, planning and delivery. TVET Inclusion Report. https://www. britishcouncil.org/sites/default/files/inclusion_of_refugees_in_tvet_report.pdf 
Brunello, G. \& Checci, D. (2006). Does school tracking affect equality of opportunity? New international evidence. IZA DP No. 2348. https://ftp.iza.org/dp2348.pdf

CEDEFOP (2011). Vocational education and training is good for you: The social benefits of VET for individuals. CEDEFOP Research Paper No: 17. Luxemburg: Publications Office of the European Union.

CEDEFOP (2017). Vocational education and training: Bridging refugee and employer needs. CEDEFOP Briefing Note. https://www.cedefop.europa.eu/files/9120_en.pdf

Crul, M., Lelie, F., Biner, Ö., Bunar, N., Keskiner, E., Kokkali, I., Schneider, J. \& Shuayb, M. (2019). How the different policies and school systems affect the inclusion of Syrian refugee children in Sweden, Germany, Greece, Lebanon and Turkey. Comparative Migration Studies, 7(10).

Czaika, M. \& de Haas, H. (2014). The globalization of migration: Has the world become more migratory? International Migration Review, 48(2), 283-323.

Çelik, Ç. \& İçduygu, A. (2018). Schools and refugee children: The case of Syrians in Turkey. International Migration, 57(2), 253-267.

De Paola, M. \& Brunello, G. (2016). Education as a tool for the economic integration of migrants. IZA Discussion Paper No. 9836.

Deniz, T. (2014). Uluslar arası göç sorunu perspektifinde Türkiye. Türkiye Sosyal Araştırmalar Dergisi, $181,174-204$.

Dinçer, M. A. \& Uysal Kolaşin, G. (2009). Türkiye'de öğrenci başarısında eşitsizliğin belirleyicileri. İstanbul: ERG.

Emin, M. N. (2016). Türkiye'deki Suriyeli çocukların eğitimi: Temel eğitim politikaları. SETA Analiz Raporları Sayı: 153, Ankara.

Emin, M. N. (2019). Türkiye'deki Suriyeli çocukların eğitimi: Geleceğin inşası. Ankara: SETA.

ERG (2014). Türkiye eğitim sisteminde eşitlik ve akademik başarı: Araştırma raporu ve analiz. http:// kasaum.ankara.edu.tr/files/2013/02/ERGe\%C5\%9FitlikWEB.22.05.14.pdf

Fazel, M., Reed, R. V., Panter-Brick, C. \& Stein, A. (2012). Mental health of displaced and refugee children resettled in high-income countries: Risk and protective factors. The Lancet, 179(9812), 266-282.

Fernandez, J. G. (2017). International legal protection of the right to education for refugees and asylumseekers developments and challenges. (Yayımlanmamış Yüksek Lisans Tezi). KU LeuvenKatholieke University. Leuven.

Gençoğlu, C. (2019). Millî bir destekleme ve yetiştirme sistemi modeli: İlkokullarda yetiştirme programı (IYYEP). Milli Eğitim Dergisi, Temel Eğitim Özel Sayısı, 853-881.

Günay, E., Atılgan, D. \& Serin, E. (2017). Dünya'da ve Türkiye'de göç yönetimi. Kahramanmaraş Sütçü İmam Üniversitesi İktisadi ve İdari Bilimler Fakültesi Dergisi, 7(2), 37-60.

Hanushek, E. A., Ruhose, J. \& Woessmann, L. (2017). Economic gains from educational reform by US States. Journal of Human Capital, 11(4), 447-486.

İçduygu, A. \& Diker, E. (2017). Labor market integration of Syrian refugees in Turkey: From refugees to settlers. The Journal of Migration Studies, 3(1), 12-35.

Jeon, S. (2019). Unlocking the potential of migrants: Cross-country analysis. OECD Reviews of Vocational Education and Training. Paris: OECD Publishing.

Karaağaç Cingöz, Z. \& Gür, B. S. (2020). Ekonomik, sosyal ve kültürel statünün akademik başarıya etkisi: PISA 2015 ve TEOG 2017 sonuçlarının karşılaştırması. İnsan ve Toplum, 10(4), 247-288. 
Kılıç, G. \& Özkor, D. (2019). Suriyeli çocukların eğitimi: Araştırma raporu. http://www.mavikalem. org/wp-content/uploads/2019/03/Suriyeli-\%C3\%87ocuklar\%C4\%B1n-E\%C4\%9FitimiAra\%C5\%9Ft\%C4\%B1rma-Raporu.pdf

Koehler, C. \& Schneider, J. (2019). Young refugees in education: The particular challenges of school systems in Europe. Comparative Migration Studies, 7(28).

Kuczera, M. (2017). Striking the right balance: Costs and benefits of apprenticeship. OECD Education Working Papers, No. 153, Paris: OECD Publishing.

Kuczera, M. \& Jeon, S. (2019). Vocational education and training in Sweden. OECD Reviews of Vocational Education and Training. Paris: OECD Publishing.

Kunyu Khisoni, D. (2016). Vocational skills training for sustainable development: A case study of youth education pack programme in Kenya's Dadaab refugee camps. (Yayımlanmamış Yüksek Lisans Tezi). Stockholm University.

MEB. (2013). Ülkemizde geçici koruma altında bulunan Suriye vatandaşlarına yönelik eğitim öğretim hizmetleri genelgesi. Ankara: Temel Eğitim Genel Müdürlüğüu.

Nusche, D. (2009). What works in migrant education? A review of evidence and policy options. OECD Education Working Papers No: 22.

OECD (2009). Education at a glance: OECD indicators 2009. Paris: OECD.

OECD (2014). How can migrants' skills be put to use? Migration Policy Debates, No:3.

OECD (2017). Finding their way: Labor market integration of refugees in Germany. OECD's Report, Paris: OECD Publishing.

OECD (2018a). The resilience of students with an immigrant background: Factors that shape well-being. OECD Reviews of Migrant Education, Paris: OECD Publishing.

OECD (2018b). Working together: Skills and labour market integration of immigrants and their children in Finland. Paris: OECD Publishing.

Önder, E. \& Güçlü, N. (2014). İlköğretimde okullar arası başarı farklılıklarını azaltmaya yönelik çözüm önerileri. Eğitim Bilimleri Dergisi, 40, 109-132.

Özer, M. (2018). The 2023 education vision and new goals in vocational and technical education. Journal of Higher Education and Science, 8(3), 425-435.

Özer, M. (2019a). Reconsidering the fundamental problems of vocational education and training in Turkey and proposed solutions for restructuring. İstanbul Üniversitesi Sosyoloji Dergisi, 39(2), 1-19.

Özer, M. (2019b). Background of problems in vocational education and training and its road map to solution in Turkey's education vision 2023. Journal of Higher Education and Science, 9(1), 1-11.

Özer, M. (2020a). Vocational education and training as "A friend in need" during coronavirus pandemic in Turkey. Bartın University Journal of Faculty of Education, 9(2), 1-7.

Özer, M. (2020b). The contribution of the strengthened capacity of vocational education and training system in Turkey to the fight against Covid-19. Yükseköğretim Dergisi, 10(2), 134-140.

Özer, M. (2020c). Türkiye'de mesleki eğitimde paradigma değişimi. Gazi Eğitim Fakültesi Dergisi, 40(2), 357-384.

Özer, M. (2020d). Mesleki eğitimde paradigma değişimi: Türkiye'nin mesleki eğitim ile imtihanı. İstanbul: Maltepe Üniversitesi Yayınları.

Özer, M. \& Perc, M. (2020). Dreams and realities of school tracking and vocational education. Palgrave Communications, 6(34).

Özer, M. \& Suna, H. E. (2020). The linkage between vocational education and labor market in Turkey: Employability and skill mismatch. Kastamonu Education Journal, 28(2), 558-569. 
Özer, M. (2021a). A promising opportunity for the integration of Syrian refugees in Turkey: New targets in accessing the labor market through vocational education and training. Bartın University Journal of Faculty of Economics and Administrative Sciences, 12(23), 239-251.

Özer, M. (2021b). A new step towards narrowing the achievement gap in Turkey: "1,000 schools in vocational education and training" project. Bartın University Journal of Faculty of Education, 10(1), 97-108.

Özer, M. (2021c). Türkiye'de mesleki eğitimi güçlendirmek için atılan yeni adımlar. Uluslararası Türk Eğitim Bilimleri Dergisi, 9(16), 1-16.

Protsch, P. \& Solga, H. (2017). Going across Europe for an apprenticeship? A factorial survey experiment on employers' hiring preferences in Germany. Journal of European Social Policy, 27(4), 387-399.

Ragazzi, E. \& Sella, L. (2013). Migration and work: The cohesive role of vocational training policies. CERIS Working Paper 201316, Institute for Economic Research on Firms and Growth, Italy.

Siviş, S. (2020). Integrating bottom-up into top-down: The role of local actors in labor market integration of Syrian refugees in Turkey. International Migration.

Suna, H. E., Tanberkan, H. \& Özer, M. (2020). Changes in literacy of students in Turkey by years and school types: Performance of students in PISA applications. Journal of Measurement and Evaluation in Education and Psychology, 11(1), 76-97.

Suna, H. E., Tanberkan, H., Gür, B. S., Perc, M. \& Özer, M. (2020a). Socioeconomic status and school type as predictors of academic achievement. Journal of Economy Culture and Society, 61, 41-64.

Suna, H. E., Gür, B. S., Gelbal, S. \& Özer, M. (2020b). Science high school students' socioeconomic background and their preferences regarding their transition into higher education. Journal of Higher Education, 10(3), 356-370.

Suna, H. E. \& Özer, M. (2021a). The achievement gap between schools and relationship between achievement and socioeconomic status in Turkey. Journal of Measurement and Evaluation in Education and Psychology, 12(1), 54-70.

Suna, H. E. \& Özer, M. (2021b). The impact of school tracking on secondary vocational education and training in Turkey. Hacettepe University Journal of Education, Advance Online Publication, doi: 10.16986/HUJE.2021068158.

Şimşek, D. (2019). Transnational activities of Syrian refugees in Turkey: Hindering or supporting integration. International Migration, 57(2), 268-282.

Tanrıkulu, F. (2017). Türkiye'de yaşayan Suriyeli çocukların eğitim sorunu ve çözüm önerileri. Liberal Düşünce Dergisi, 22(86), 127-144.

Tanrikulu, F. (2020). Comparing of migrants education policies of Turkey and Germany. International Conference on Social Science Research, ICONSR 2-5 September, Budva, Montenegro, 31-40.

Taşkın, P. \& Erdemli, Ö. (2018). Education for Syrian refugees: Problems faced by teachers in Turkey. Eurasian Journal of Educational Research, 75, 155-178.

Taştan, C. \& Çelik, Z. (2017). Türkiye'de Suriyeli çocukların eğitimi: Güçlükler ve öneriler. Ankara: Eğitim-Bir-Sen Stratejik Araştırmalar Merkezi.

Tunga, Y., Engin, G. \& Çağıltay, K. (2020). A Literature review on the issues encountered in educating Syrian children in Turkey. Inonu University Journal of the Faculty of Education, 21(1), 317-333.

Tüzün, I. (2017). Türkiye'de mülteci çocukların eğitim hakkını ve karşılıklı uyumu destekleyen yaklaşımlar, politikalar ve uygulamalar. European Liberal Forum. http://liberalforum.eu/wpcontent/uploads/2018/09/publication_final.pdf

Willems, K. \& Vernimmen, J. (2018). The fundamental human right to education for refugees: Some legal remarks. European Educational Research Journal, 17(2), 219-232. 
UNESCO \& UNHCR (2016). No more excuses: Provide education to all forcibly displaced people. Global Education Monitoring Report, Policy Paper 26, Paris: UNESCO.

UNESCO (2019). Enforcing the right to education of refugees: A policy perspective. Working Papers on Education Policy No.8. https://www.gcedclearinghouse.org/sites/default/files/ resources/190208eng.pdf

UNEVOC (2019). Human migration and TVET: Discussion paper. https://unevoc.unesco.org/pub/30002eng.pdf

UNHCR (2018). What a waste: Ensure migrants and refugees' qualifications and prior learning are recognized. UNHCR Policy Paper 37. https://www.unhcr.org/5c3c6f1f14

United Nations (2015). Trends in international migration 2015. Population Facts, No. 2015/4. https:// www.un.org/en/development/desa/population/migration/publications/populationfacts/docs/ MigrationPopFacts20154.pdf

Unutulmaz, K. O. (2019). Turkey's education policies towards Syrian refugees: A macro-level analysis. International Migration, 57(2), 235-252.

Zschirnt, E. \& Ruedin, D. (2016). Ethnic discrimination in hiring decisions: A meta-analysis of correspondence test 1990-2015. Journal of Ethnic and Migration Studies, 42(7), 1-19. 